\title{
Aeromonas media, a New Species Isolated from River Wateı
}

\author{
D. A. ALLEN,${ }^{1}$ B. AUSTIN,${ }^{3}+$ AND R. R. COLWELL ${ }^{2 *}$ \\ Marine-Estuarine-Environmental Sciences Program ${ }^{1}$ and Department of Microbiology, ${ }^{2}$ University of \\ Maryland, College Park, Maryland 20742; and Ministry of Agriculture, Fisheries and Food, Directorate of \\ Fisheries Research, Fish Diseases Laboratory, Weymouth, Dorset, DT4 8UB, England ${ }^{3}$
}

During a survey for the presence of Aeromonas salmonicida, 45 Aeromonas isolates which could not be classified in the existing named species of the genus were recovered from water obtained from the River Avon in Hampshire, England. On the basis of a numerical taxonomy study, these isolates were clustered in three homogeneous phena. Phenon 1 was identified as a new species of Aeromonas, for which we propose the name Aeromonas media; strain $\mathrm{R}_{\mathrm{M}}$ (= ATCC 33907) is the type strain of this species.

The taxonomy of Aeromonas is unsettled despite all of the attention which has been focused on this genus. Specifically, a satisfactory classification has to be resolved for the motile organisms (i.e., Aeromonas hydrophila, Aeromonas punctata and Aeromonas sobria) (12). In contrast, the nonmotile species Aeromonas salmonicida is regarded as relatively homogeneous ( 7 , 29).

The motile aeromonads are ubiquitous inhabitants of freshwater and estuarine environments $(9,12,26)$. In particular, A. hydrophila comprises a dominant component of the natural microflora of fish $(27,34)$. Indeed, this organism has been implicated as an opportunistic and primary pathogen of a diverse range of aquatic and terrestrial animals, including fish (4) and humans (11). In contrast, $A$. salmonicida has been recovered exclusively from fish tissues (16); in fact, the description in Bergey's Manual of Determinative Bacteriology mentions that this organism is not found in surface waters, but only as an obligate fish pathogen that causes furunculosis in salmonid fish (25).

The identification of fresh isolates of $A$. salmonicida relies on the absence of motility and on the production of a brown diffusible pigment on tryptone-soya agar (TSA). Thus, during a microbiological survey of a trout farm situated on the River Avon, England, a group of bacterial isolates possessing some characteristics of $A$. salmonicida were recovered from water samples plated on peptone-beef extract-glycogen agar (17), a medium selective for the isolation of Aeromonas spp. On the basis of overall similarity, which was computed by using numerical taxonomy methods, these organisms could not

+ Address reprint requests to: Dr. B. Austin, Fish Diseases Laboratory, Weymouth, Dorset, DT4 8UB, England. be classified as members of previously described species of Aeromonas. Thus, we propose that these organisms be recognized as a new species, Aeromonas media.

\section{MATERIALS AND METHODS}

Collection of samples. Water samples were collected aseptically with a sampler (see below) from selected locations at a trout farm situated on the River Avon in Hampshire, England. These samples included water taken from the river approximately $100 \mathrm{~m}$ upstream from the fish farm, water from each of three earth fishponds, and water from a feeder channel derived from the river and located about $1 \mathrm{~km}$ downstream from the farm. The site was sampled at monthly intervals, beginning in October 1980 and ending in November 1981.

In addition, a survey of the River Avon was carried out, in which water samples from 11 stations on the river were collected, beginning at its source at the Kennett and Avon Canal and then at approximately $10-\mathrm{km}$ intervals until the river mouth at Christchurch, Dorset, was reached. This survey was done twice in entirety, once in September 1981, and again in November 1981, and also once for the five stations downstream from the fish farm to the river mouth in June 1981.

All water samples were collected by using presterilized plastic bottles (Dippas; Sterilin Ltd., Teddington, Middlesex, England). Samples were processed within 30 min of collection at the fish farm sites. River survey water samples were processed within $2 \mathrm{~h}$ of collection.

Examination of samples. The water samples were diluted $10^{-4}$ with river water sterilized by passage through $0.22-\mu \mathrm{m}$ membrane filters. 'Samples $(0.1 \mathrm{ml})$ were pipetted in duplicate onto the surface of TSA (Oxoid Ltd., Basingstoke, Hampshire, England). In addition, 1- and $0.1-\mathrm{ml}$ portions of the water samples were incorporated into peptone-beef extract-glycogen agar. All plates were incubated at $15^{\circ} \mathrm{C}$ for up to 14 days.

Isolation and maintenance of strains. A total of 38 bacterial isolates demonstrating several key characteristics of $A$. salmonicida (gram-negative, oxidase- and catalase-positive, nonmotile, fermentative, rod- 
TABLE 1. Strains used in this study

\begin{tabular}{|c|c|c|c|}
\hline Phenon & $\operatorname{Strain}(s)^{a}$ & Source of isolation & Date of isolation \\
\hline \multirow[t]{8}{*}{1} & $\mathrm{R}_{\mathrm{L}}, \mathrm{R}_{\mathrm{M}}^{\mathrm{T}}, \mathrm{RS}$ & Fish farm effluent & October 1980 \\
\hline & $\mathrm{S} 1, \mathrm{~S} 2$ & Sopley & June 1981 \\
\hline & Junc2, EW, I2, UP3, EN1 & $\begin{array}{l}\text { Road Junction, Etchilhampton } \\
\text { water, Ibsley, Upavon, Enford }\end{array}$ & November 1981 \\
\hline & $\mathrm{P} 43$ & Fish farm (pond 43), River Avon & December 1980 \\
\hline & $\mathrm{Rd}$ & Fish farm effluent, River Avon & December 1980 \\
\hline & $\mathrm{P} 1 \mathrm{~A}$ & Fish farm (pond 1), River Avon & February 1981 \\
\hline & P1E & Fish farm (pond 1), River Avon & August 1981 \\
\hline & $\mathrm{CC} 2$ & Mouth of River Avon (Christchurch) & November 1981 \\
\hline \multirow[t]{21}{*}{2} & B & Inflow to fish farm & January 1981 \\
\hline & $\mathrm{F} 2, \mathrm{~B} 2$ & Effluent, inflow to fish farm & March 1981 \\
\hline & B3 & Inflow to fish farm & April 1981 \\
\hline & I1 & Ibsley & June 1981 \\
\hline & Junc1, NET1 & Road Junction & September 1981 \\
\hline & $\mathrm{B} 4, \mathrm{~B} 5$ & Salterton & October 1981 \\
\hline & S3 & Inflow to fish farm & November 1981 \\
\hline & $\mathrm{P} 12 \mathrm{~b}$ & Fish farm (pond 1) & October 1980 \\
\hline & P1B & Fish farm (pond 1) & April 1981 \\
\hline & P1C, P1D & Fish farm (pond 1) & June 1981 \\
\hline & $\mathrm{P} 1 \mathrm{~F}$ & Fish farm (pond 1) & October 1981 \\
\hline & P43b & Fish farm (pond 43) & May 1981 \\
\hline & $\mathrm{P} 43 \mathrm{c}$ & Fish farm (pond 43) & June 1981 \\
\hline & P43d & Fish farm (pond 43) & August 1981 \\
\hline & $\mathrm{P} 43 \mathrm{e}$ & Fish farm (pond 43) & September 1981 \\
\hline & P43f & Fish farm (pond 43) & October 1981 \\
\hline & F4 & Fish farm effluent & August 1981 \\
\hline & F5, Rd2 & Fish farm effluent & September 1981 \\
\hline & Rd3, NET2 & Fish farm effluent & October 1981 \\
\hline & $\mathrm{CC} 1$ & Mouth of River Avon (Christchurch) & June 1981 \\
\hline & $\mathrm{P} 43 \mathrm{a}$ & Fish farm (pond 43) & June 1981 \\
\hline 3 & I3, UP1, UP2 & Ibsley, Upavon & November 1981 \\
\hline \multirow[t]{2}{*}{4} & A. hydrophila ATCC $7966^{\mathrm{T}}$ & & \\
\hline & A. sobria Popoff 310 & & \\
\hline \multirow[t]{2}{*}{5} & A. punctata subsp. caviae ATCC $15468^{\mathrm{T}}$ & & \\
\hline & A. hydrophila NCTC $7810^{\mathrm{T}}$ & & \\
\hline \multirow[t]{3}{*}{6} & $\begin{array}{l}\text { A. salmonicida NCIB } 833^{\mathrm{T}} \text {, CCM } 1307 \text {, } \\
\text { CCM } 1318\end{array}$ & & \\
\hline & A. salmonicida $26 / 78$ & Oncorhynchus sp., Scotland & 1978 \\
\hline & A. salmonicida $22 / 81$ & Salmo trutta, England & 1981 \\
\hline
\end{tabular}

${ }^{a}$ ATCC, American Type Culture Collection, Rockville, Md.; CCM, Czechoslovak Collection of Microorganisms, Brno, Czechoslovakia; NCIB, National Collection of Industrial Bacteria, Aberdeen, Scotland; Popoff, M. Popoff, Pasteur Institute, Paris, France; NCTC, National Collection of Type Cultures, Colindale, London, England. $\mathrm{T}=$ type strain.

shaped organisms producing a brown diffusible pigment) and 7 closely related but motile isolates that also produced a brown pigment were recovered from the water samples (Table 1). All organisms were inoculated onto TSA slopes and maintained at room temperature. Subculturing was done every 4 weeks. In addition, stock cultures were preserved in tryptone-soya broth (Oxoid) and glycerol at $-20^{\circ} \mathrm{C}$.

Reference cultures. The environmental isolates were compared with 10 reference strains, including $A$. punctata subsp. caviae ATCC $15468^{\mathrm{T}}, A$. hydrophila ATCC $7966^{\mathrm{T}}$ and NCTC $7810^{\mathrm{T}}$, A. sobria Popoff 310 , a brown-pigmented $A$. hydrophila (strain $37 / 75$ ), and $A$. salmonicida CCM 1307, CCM 1318, NCIB 833 ${ }^{\mathrm{T}}, 26 / 78$, and $22 / 81$.

Characterization of the isolates. All strains were examined for 124 characteristics as described previously $(2,8)$ or below. Whenever possible, TSA was used as the basal medium, and all inoculated media were incubated at $22^{\circ} \mathrm{C}$ for 14 days, unless indicated otherwise, before results were recorded.

Colonial morphology and micromorphology. Colony morphology on TSA was recorded after incubation for 7 days at $22^{\circ} \mathrm{C}$. Motility was determined from wet preparations. Gliding motility was assessed by the presence of swarming growth on Cytophaga agar (Oxoid).

Biochemical characteristics. Hydrolysis of gelatin and decarboxylation of arginine, lysine, and ornithine were tested by using the methods of Smith and Goodner (28) and Moeller (18), respectively. The production of $\mathrm{H}_{2} \mathrm{~S}$ (Kligler iron agar [Oxoid]), the hydrolysis of $5 \%(\mathrm{wt} / \mathrm{vol}$ ) sheep blood (Oxoid) in TSA, the hydrolysis of urea (Oxoid), and the utilization of citrate (Oxoid) were recorded after incubation for 7 days at $22^{\circ} \mathrm{C}$. 


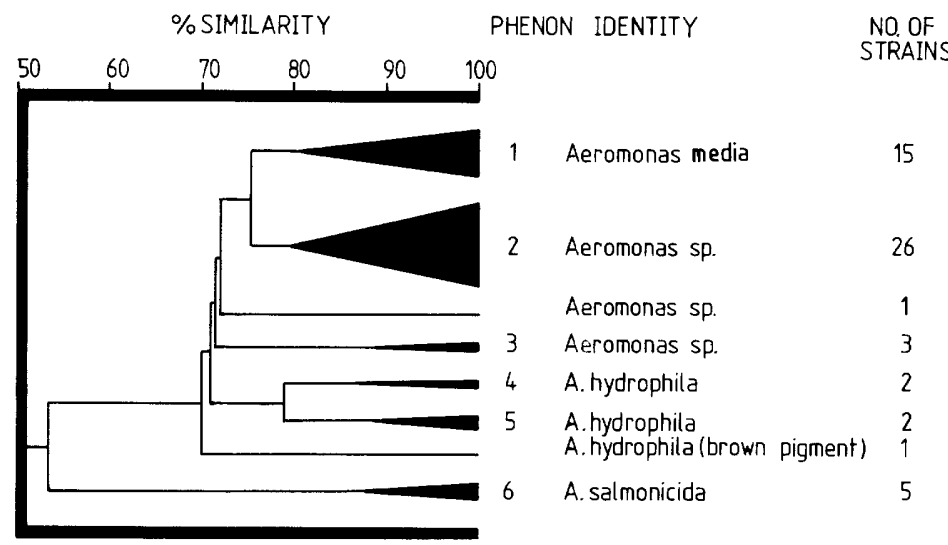

FIG. 1. Simplified dendrogram based on the Jaccard coefficient and unweighted average linkage.

Growth. Growth on cysteine-lactose electrolyte-deficient agar (Oxoid) and growth on thiosulfate-citratebile salt-sucrose agar (Oxoid) were assessed after incubation for 7 days at $22^{\circ} \mathrm{C}$.

Susceptibility to antibacterial agents. Susceptibilities to antibiotics were determined by a modification of the method of Allen et al. (1). Zones of clearing around antibiotic disks placed on Mueller-Hinton agar (Oxoid) were measured as soon as growth could be detected (i.e., after incubation for $24 \mathrm{~h}$ at $22^{\circ} \mathrm{C}$ ). Susceptibility to 2,4-diamino-6,7-diisopropyl pteridine (vibriostatic agent 0/129) was recorded after incubation for $24 \mathrm{~h}$ at $22^{\circ} \mathrm{C}$.

Computer analyses. The 55 bacterial strains studied were examined for a total of 124 unit characters, which were coded in a binary format by scoring positive and negative characters as 1 and 0 , respectively. Similarities between strains were calculated by using the simple matching (32) and Jaccard (30) coefficients. Sorted similarity matrices and dendrograms were obtained by using the unweighted average linkage algorithm (31).

Determination of deoxyribonucleic acid base composition. The guanine-plus-cytosine $(\mathrm{G}+\mathrm{C})$ contents of purified deoxyribonucleic acids prepared from representative organisms (14) were determined by measuring the thermal denaturation temperatures (15) with a Pye Unicam model SP 1800 recording spectrophotometer at $260 \mathrm{~nm}$; this instrument was programmed for temperature increases of $1.0^{\circ} \mathrm{C} / \mathrm{min}$. $\mathrm{G}+\mathrm{C}$ contents were calculated from the thermal denaturation temperatures by using the equation of De Ley (6).

Electron microscopy. Cells of representative isolates were grown and harvested by the procedure of Austin et al. (3). Cell suspensions were negatively stained with $1 \%(\mathrm{wt} / \mathrm{vol})$ methylamine tungstate (EM Scope Laboratories Ltd., Ashford, Kent, England) and examined with a JEOL model CX 100 transmission electron microscope.

\section{RESULTS}

Clustering of the isolates. Six phena and two single-member clusters were defined at the $80 \%$ similarity level by our analysis when the Jaccard coefficient was used (Fig. 1). Thus, the 45 environmental isolates were clustered in phena 1 through 3. However, these isolates showed little affinity to the reference cultures of Aeromonas included in the analysis. The latter fell into three well-separated clusters, phena 4 through 6 . Nevertheless, we determined that phena 1 through 3 were more similar to $A$. hydrophila than to $A$. salmonicida (Fig. 1).

Characterization of the environmental isolates. All environmental isolates possessed the following properties of the genus Aeromonas: straight, gram-negative, fermentative, oxidase- and catalase-positive, rod-shaped organisms that produce a brown diffusible pigment on TSA, utilize a wide range of carbon compounds for energy and growth, and have a $\mathrm{G}+\mathrm{C}$ content between 57 and $63 \mathrm{~mol} \%$ (Table 2) (25). However, it was not possible to identify these isolates exactly by using the diagnostic keys in Bergey's Manual (5) or the diagnostic scheme of Sannohe et al. (21).

Phenon 1 contained 15 isolates, which were nonmotile rod-shaped organisms that were approximately 1 by $2 \mu \mathrm{m}$ and had rounded ends (Fig. 2); these isolates formed round, raised, entire, shiny colonies $2 \mathrm{~mm}$ in diameter on TSA after incubation for 2 days at $22^{\circ} \mathrm{C}$. The results of other tests are shown in Tables 2 and 3. This phenon was considered a new species of Aeromonas, for which we propose the name $A$. media.

Phenon 2 included 26 isolates with colonial morphologies and micromorphologies similar to those of the isolates in phenon 1. However, some phenon 2 isolates were motile by means of single polar flagella. In general, these isolates were more reactive than the organisms in phenon 1; they produced arginine dihydrolase and $\beta$-galactosidase, but not $\mathrm{H}_{2} \mathrm{~S}$, phosphatase, or lysine or ornithine decarboxylase. Gluconate oxidation, the Voges-Proskauer reaction, and 
TABLE 2. Diagnostic characters of Aeromonas spp. examined in this study ${ }^{a}$

\begin{tabular}{|c|c|c|c|c|c|c|}
\hline \multirow{2}{*}{ Character } & \multicolumn{6}{|c|}{ Phenon } \\
\hline & 1 & 2 & 3 & 4 & 5 & 6 \\
\hline Motility & $-b$ & V & - & + & + & - \\
\hline Diffusible brown pigment & + & + & + & - & - & + \\
\hline Growth on $5 \%$ (wt/vol) $\mathrm{NaCl}$ & - & - & - & - & + & - \\
\hline Indole production & $\mathrm{V}$ & V & + & + & + & - \\
\hline Phosphatase production & - & - & - & + & + & V \\
\hline Growth at $37^{\circ} \mathrm{C}$ & + & + & + & + & + & - \\
\hline Methyl red test & + & + & + & + & - & + \\
\hline \multicolumn{7}{|l|}{ Degradation of: } \\
\hline Casein & $\mathrm{V}$ & V & + & + & + & - \\
\hline Elastin & - & - & - & + & $\mathrm{V}$ & + \\
\hline Tyrosine & $\mathrm{V}$ & V & - & + & + & - \\
\hline \multicolumn{7}{|l|}{ Utilization of: } \\
\hline Alanine & V & + & + & + & + & - \\
\hline Cellobiose & - & + & - & - & - & - \\
\hline Fructose & - & + & V & + & + & + \\
\hline Galactose & V & + & + & + & + & + \\
\hline Lactose & V & + & + & - & - & - \\
\hline Maltose & $\mathrm{V}$ & + & - & + & + & + \\
\hline Mannose & $\mathrm{V}$ & + & + & + & + & - \\
\hline Ribose & $\mathrm{V}$ & + & + & + & + & + \\
\hline Sodium butyrate & $\mathrm{V}$ & + & - & + & + & - \\
\hline Sodium citrate & $\mathrm{V}$ & + & - & V & + & - \\
\hline Sodium formate & - & - & - & + & - & - \\
\hline Sodium malate & V & + & V & + & + & + \\
\hline Sucrose & - & + & - & + & + & - \\
\hline Trehalose & - & + & - & + & + & + \\
\hline
\end{tabular}

a In addition, the $\mathrm{G}+\mathrm{C}$ contents of the phena are as follows: phenon 1, $62.3 \mathrm{~mol} \%$; phenon 2, $61.5 \mathrm{~mol} \%$; phenon 3, undetermined; phenon 4, 57.1 mol\%; phenon 5, $61.6 \mathrm{~mol} \%$; phenon $6,62.7 \mathrm{~mol} \%$.

${ }^{b}+, \geq 80 \%$ positive responses;,$- \leq 20 \%$ positive responses; V, 21 to $79 \%$ positive responses.

phenylalanine deaminase were negative. Nitrate reduction and the methyl red test were positive. Growth occurred at 4 and $37^{\circ} \mathrm{C}$ and in 0 to $3 \%$ sodium chloride. Esculin, blood, DNA, gelatin, ribonucleic acid starch, Tween 20, Tween 40, Tween 60 , and Tween 80 were degraded, but cellulose, elastin, xanthine, and urea were not. DL- $(\alpha)$-Alanine, L- $(-)$-arabinose, D- $(+)$-cellobiose, $\mathrm{D}-(-)$-fructose, $\mathrm{D}-(+)$-mannose, L-proline, D-(-)-ribose, L-serine, sodium acetate, sodium butyrate, sodium glutamate, sodium malate, sodium pyruvate, sodium succinate, sucrose, and $\mathrm{D}(+)$-trehalose were utilized as sole sources of carbon for energy and growth, but adonitol, meso-erythritol, ethanol, $p$-hydroxybenzoic acid, meso-inositol, inulin, L-leucine, D- $(+)$-melezitose, D-(+)-sorbitol, and D-(+)-xylose were not. The $\mathrm{G}+\mathrm{C}$ content of a representative isolate was $61.5 \pm 0.5 \mathrm{~mol} \%$. Although these characteristics do not match precisely the description of any Aeromonas species, there are a number of properties in common with $A$. hydrophila (5) (namely, motility and utilization of adonitol, alanine, arabinose, fructose, galactose, inositol, inulin, maltose, mannitol, melezitose, serine, sodium glutamate, sucrose, trehalose, and $x y-$ lose). Therefore, phenon 2 is not elevated to species status at this time; instead, further work should be carried out to elucidate more fully the taxonomic position of these organisms.

The diagnostic characteristics of phenon 3 are shown in Table 2. However, there are too few isolates for a meaningful taxonomic discussion until studies in progress are completed.

\section{DISCUSSION}

The taxonomy of Aeromonas has received great attention in recent years. However, some confusion about the classification of species within this genus remains. For example, at one time, A. salmonicida was transferred to a separate genus, Necromonas (29); this is in contrast to current opinion, which considers the organisms called $A$. hydrophila and $A$. salmonicida genotypically to be bona fide members of the same genus (i.e., Aeromonas) $(13,25)$. Nevertheless, atypical representatives of Aeromonas have been reported (33). In fact, results of some environmental studies have provided good evidence of species diversity, notably for $A$. hydrophila (10). In this case, Holder-Franklin et al. (10) described environmental isolates of $A$. hydrophila which had phenotypic traits and $\mathrm{G}+\mathrm{C}$ contents that were inconsistent with the description of the taxon (25). Thus, it appears that a reappraisal of the taxonomy of $A$. hydrophila is needed, and this may clarify the position of phenon 2.

At present, the classification of the genus Aeromonas follows the work of Schubert (23-

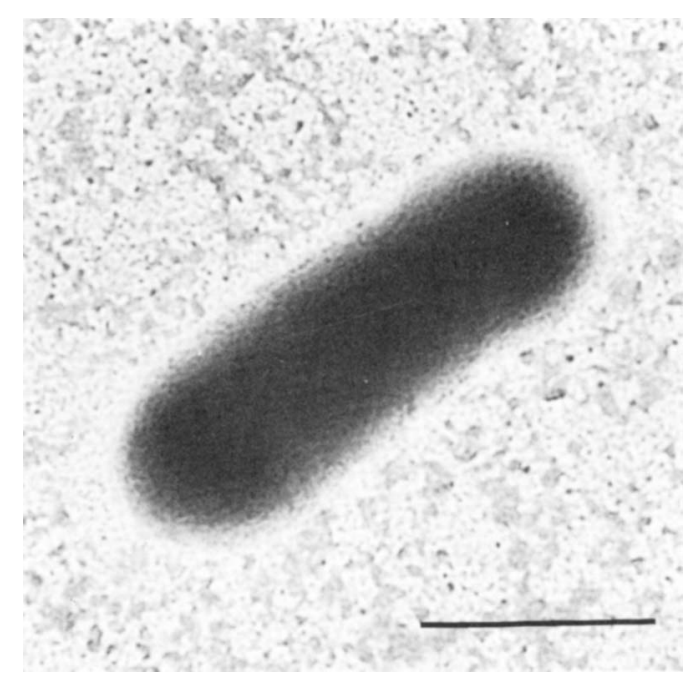

FIG. 2. Negatively stained cell of strain $R_{m}{ }^{T}$. Bar $=1 \mu \mathrm{m}$. 
TABLE 3. Differential characteristics of strains in phenon 1

\begin{tabular}{|c|c|c|}
\hline \multirow{2}{*}{ Character } & \multicolumn{2}{|c|}{ Reaction of: } \\
\hline & Phenon 1 & Strain $R_{M}{ }^{1}$ \\
\hline Indole production & $\mathrm{V}^{a}$ & + \\
\hline \multicolumn{3}{|l|}{ Growth on: } \\
\hline $3 \%$ (wt/vol) $\mathrm{NaCl}$ & + & - \\
\hline $4 \%$ (wt/vol) $\mathrm{NaCl}$ & V & - \\
\hline $5 \%$ (wt/vol) $\mathrm{NaCl}$ & - & - \\
\hline $\mathrm{CLED}^{b}$ & + & + \\
\hline MacConkey agar & + & + \\
\hline TCBS $^{c}$ & V & - \\
\hline \multicolumn{3}{|l|}{ Degradation of: } \\
\hline Esculin & V & - \\
\hline Chitin & V & + \\
\hline DNA & V & - \\
\hline Tyrosine & V & - \\
\hline \multicolumn{3}{|l|}{ Utilization of: } \\
\hline DL- $(\alpha)$-Alanine & V & + \\
\hline Calcium lactate & V & - \\
\hline D- $(+)$-Galactose & $\mathrm{V}$ & - \\
\hline Lactose & V & - \\
\hline Maltose & V & - \\
\hline D- $(+)$-Mannose & V & - \\
\hline D-(-)-Ribose & V & - \\
\hline Sodium butryate & V & - \\
\hline Sodium citrate & V & - \\
\hline Sodium malate & V & + \\
\hline \multicolumn{3}{|l|}{ Susceptibility to: } \\
\hline Erythromycin & V & + \\
\hline Streptomycin & - & + \\
\hline \multicolumn{3}{|c|}{$\begin{array}{l}a+\text {, Positive reaction; }- \text {, negative reaction; } V \text {, } \\
\text { variable reaction. }\end{array}$} \\
\hline
\end{tabular}

$25)$, who recognized three species, namely, $A$. hydrophila (including $A$. hydrophila subsp. anaerogenes, A. hydrophila subsp. hydrophila, and $A$. hydrophila subsp. proteolytica), A. punctata (including $A$. punctata subsp. caviae and $A$. punctata subsp. punctata), and A. salmonicida (including $A$. salmonicida subsp. achromogenes, A. salmonicida subsp. masoucida, and A. salmonicida subsp. salmonicida). However, the validity of $A$. punctata as a separate species has been questioned insofar as Popoff and Véron (19) consider it to be a synonym of A. hydrophila. Our study supports this view because the type strains of $A$. punctata subsp. caviae (strain ATCC 15468) and $A$. hydrophila (strain NCTC 7810) clustered together in phenon 5. These strains were distinct from A. sobria (phenon 4), which Popoff and Véron (19) described as a new species of Aeromonas.

Aeromonas spp. that produce a brown diffusible pigment have been isolated frequently from aquatic environments. Furthermore, motile rodshaped organisms classified as Aeromonas li- quefaciens (20) (an objective synonym of $A$. hydrophila [25]) have been isolated from salmon. Nonmotile organisms (H. LeClerc, Ph.D. thesis, Faculté de Medicine et de Pharmacie de Lille, Lille, France, 1962) distinct from A. salmonicida have been described and identified as A. hydrophila (22), contrary to the view that the members of $A$. hydrophila are all motile (25). Strains that possess selected characteristics of A. salmonicida are common in aquatic environments $(10,21)$, and Sannohe et al. (21) suggested that nonmotile aeromonads recovered from aquarium water in Japan belong in an as-yetundescribed species of Aeromonas related to $A$. salmonicida. A comparison of phenotypic and genotypic traits shows that these organisms are very unlike the strains in phenon 1 . Consequently, we decided that phenon 1 is not closely related to any of the previously described Aeromonas species (5). Therefore, we concluded that these strains represent a new species of the genus Aeromonas, for which we propose the name Aeromonas media (me.' di. a. f. L. adj. medius in the middle).

Description of Aeromonas media sp. nov. Gram-negative, nonmotile rod-shaped cells approximately 1 by $2 \mu \mathrm{m}$ with rounded ends (Fig. 2).

Colonies on TSA are cream, shiny, smooth, round, raised, entire, and $2 \mathrm{~mm}$ in diameter after incubation for 2 days at $22^{\circ} \mathrm{C}$.

A diffusible brown, nonfluorescent pigment is produced.

Cultures in peptone broth are uniformly turbid.

Chemoorganotrophic; metabolism is fermentative.

Nitrates are reduced.

Temperature range for growth: grows at 4 and $37^{\circ} \mathrm{C}$ but not at $42^{\circ} \mathrm{C}$.

Growth occurs in 0 to $3 \%(\mathrm{wt} / \mathrm{vol})$ sodium chloride.

Catalase and oxidase are produced.

Arginine dihydrolase is produced.

Lysine and ornithine are not decarboxylated.

Blood, gelatin, starch, ribonucleic acid, Tween 20, Tween 40, Tween 60, and Tween 80 are degraded, but cellulose, elastin, lecithin, xanthine, and urea, are not.

$\beta$-Galactosidase is produced, but $\mathrm{H}_{2} \mathrm{~S}$ and phosphatase are not.

The methyl red test is positive, but the VogesProskauer and gluconate oxidation tests are negative.

Susceptible to chloramphenicol, chlortetracycline, colistin sulfate, furazolidone, gentamicin, kanamycin, neomycin, nitrofurantoin, oxytetracycline, and tetracycline but not to ampicillin, cloxacillin, novobiocin, vibriostatic agent $0 / 129$, penicillin $G$, or sulfafurazole. 
Utilizes L(-)-arabinose, glycerol, mannitol, Lproline, L-serine, sodium acetate, sodium glutamate, sodium pyruvate, and sodium succinate as sole carbon sources for energy and growth, but does not utilize adonitol, D-(+)-cellobiose, meso-erythritol, ethanol, D-(-)-fructose, mesoinositol, inulin, L-leucine, D-(+)-melezitose, $p$ hydroxybenzoic acid, D-(+)-raffinose, sodium benzoate, sodium formate, sodium malonate, $\mathrm{D}$ $(-)$-sorbitol, sucrose, D-(+)-trehalose, L-valine or D-(+)-xylose.

$\mathrm{G}+\mathrm{C}$ content of deoxyribonucleic acid: 62.3 $\pm 0.2 \mathrm{~mol} \%$.

The type strain is strain $R_{m}$; a culture of this strain has been deposited with the American Type Culture Collection, Rockville, Md., as ATCC 33907.

Other characteristics of the type strain are shown in Table 3.

\section{ACKNOWLEDGMENTS}

D.A.A. was supported by a Sea Grant Fellowship.

Assistance in obtaining computer analyses was provided by M. Goodfellow and P. West.

\section{LITERATURE CITED}

1. Allen, D. A., B. Austin, and R. R. Colwell. 1977. Antibiotic resistance patterns of metal-tolerant bacteria isolated from an estuary. Antimicrob. Agents Chemother. 12:545547.

2. Austin, B., M. Goodfellow, and C. H. Dickinson. 1978 Numerical taxonomy of phylloplane bacteria isolated from Lolium perenne. J. Gen. Microbiol. 104:139-155.

3. Austin, B., A. Zachary, and R. R. Colwell. 1978. Recognition of Beneckea natriegans (Payne et al.) Baumann et al as a member of the genus Vibrio, as previously proposed by Webb and Payne. Int. J. Syst. Bacteriol. 28:315-317.

4. Boulanger, Y., R. Lallier, and G. Cousineau. 1977. Isolation of enterotoxigenic Aeromonas from fish. Can. J. Microbiol. 23:1161-1164

5. Buchanan, R. E., and N. E. Gibbons (ed.). 1974. Bergey's manual of determinative bacteriology, 8th ed. The Williams \& Wilkins Co., Baltimore.

6. De Ley, J. 1970. Re-examination of the association between melting point, buoyant density, and chemical base composition of deoxyribonucleic acid. J. Bacteriol. 101:738-754

7. Ewing, W. H., R. Hugh, and J. C. Johnson. 1961. Studies on the Aeromonas group. U.S. Department of Health, Education and Welfare Communicable Disease Center, Atlanta, Ga.

8. Goodfellow, M., B. Austin, and C. H. Dickinson. 1976. Numerical taxonomy of some yellow pigmented bacteria isolated from plants. J. Gen. Microbiol. 97:219-233.

9. Hazen, T. C., C. B. Fliermanns, R. F. Hirsch, and G. W. Esch. 1978. Prevalence and distribution of Aeromonas hydrophila in the United States. Appl. Environ. Microbiol. 36:731-738.

10. Holder-Franklin, M. A., A. Thorpe, and C. J. Cormier. 1981. Comparison of numerical taxonomy and DNADNA hybridization in diurnal studies of river bacteria. Can. J. Microbiol. 27:1165-1184.

11. Joseph, S. W., O. P. Daily, W. S. Hunt, R. J. Seidler, D. A. Allen, and R. R. Colwell. 1979. Aeromonas primary wound infection of a diver in polluted waters. J. Clin. Microbiol. 10:46-49.

12. Kaper, J. B., H. Lockman, R. R. Colwell, and S. W. Joseph. 1981. Aeromonas hydrophila: ecology and toxige- nicity of isolates from an estuary. J. Appl. Bacteriol. 50:359-377.

13. MacInnes, J. I., T. J. Trust, and J. H. Crosa. 1979. Deoxyribonucleic acid relationships among members of the genus Aeromonas. Can. J. Microbiol. 25:579-586.

14. Marmur, J. 1961. A procedure for the isolation of deoxyribonucleic acid from microorganisms. J. Mol. Biol. 3:208-218.

15. Marmur, J., and P. Doty. 1962. Determination of the base composition of deoxyribonucleic acid from its thermal denaturation temperature. J. Mol. Biol. 5:109-118.

16. McCarthy, D. H. 1978. Some ecological aspects of the bacterial fish pathogen Aeromonas salmonicida. Soc. Appl. Bacteriol. Symp. Ser. 6:299-324.

17. McCoy, R. H., and K. S. Pilcher. 1974. Peptone beef extract glycogen agar, a selective and differential Aeromonas medium. J. Fish. Res. Board Can. 31:1553-1555.

18. Moeller, V. 1955. Simplified tests for some amino acid decarboxylases and for the arginine dihydrolase system. Acta Pathol. Microbiol. Scand. 36:158-172.

19. Popoff, M., and M. Véron. 1976. A taxonomic study of the Aeromonas hydrophila-Aeromonas punctata group. J. Gen. Microbiol. 94:11-22.

20. Ross, A. J. 1962. Isolation of a pigment-producing strain of Aeromonas liquefaciens from silver salmon (Oncorhynchus kisutch). J. Bacteriol. 84:590-591.

21. Sannohe, H., Y. Ezura, and T. Kimura. 1981. A taxonomic study of bacteria belonging to the genus Aeromonas isolated from the water of an aquarium rearing guppy Peocillia reticulata Peters-isolation and characterization of Aeromonas spp. Bull. Jpn. Soc. Sci. Fish. 47:777-782.

22. Schubert, R. H.W. 1964. Taxonomic der anerogenen Aeromonaden. Zentralbl. Bakteriol. Parasitenkd. Infektionskr. Hyg. Abt. 1 Orig. 193:343-352.

23. Schubert, R. H. W. 1967 . The taxonomy and nomenclature of the genus Aeromonas Kluyver and van Niel 1936. I. Suggestions on the taxonomy and nomenclature of the aerogenic Aeromonas species. Int. J. Syst. Bacteriol. 17:23-37.

24. Schubert, R. H. W. 1969. Infrasubspecific taxonomy of Aeromonas hydrophila (Chester 1901) Stanier 1943. Zentralbl. Bakteriol. Parasitenkd. Infektionskr. Hyg. Abt. 1 , Orig. Reihe A 211:406-408.

25. Schubert, R. H. W. 1974. Genus II. Aeromonas Kluyver and van Niel 1936, 398, p. 345-348. In R. E. Buchanan and N. E. Gibbons (ed.), Bergey's manual of determinative bacteriology, 8 th ed. The Williams \& Wilkins Co., Baltimore.

26. Seidler, R. J., D. A. Allen, H. Lockman, R. R. Colwell, S. W. Joseph, and O. P. Daily. 1980. Isolation, enumeration, and characterization of Aeromonas from polluted waters encountered in diving operations. Appl. Environ. Microbiol. 39:1010-1018.

27. Simidu, U., K. Ashino, and E. Kaneko. 1971. Bacterial flora of phyto- and zooplankton in the inshore water of Japan. Can. J. Microbiol. 17:1157-1160.

28. Smith, H. L., and K. Goodner. 1958. Detection of bacterial gelatinases by gelatin-agar plate methods. J. Bacteriol. 76:662-665.

29. Smith, I. W. 1963. The classification of "Bacterium salmonicida." J. Gen. Microbiol. 33:263-274.

30. Sneath, P. H. A. 1957. The application of computers to taxonomy. J. Gen. Microbiol. 17:201-226.

31. Sneath, P. H. A., and R. R. Sokal. 1973. Numerical taxonomy: the principles and practice of numerical classification, 2nd ed. W. H. Freeman \& Co., San Francisco.

32. Sokal, R. R., and C. D. Michener. 1958. A statistical method for evaluating systematic relationships. Univ. Kans. Sci. Bull. 38:1409-1438.

33. Trust, T. J., A. G. Khouri, R. A. Austen, and L. D. Ashburner. 1980. First isolation in Australia of atypical Aeromonas salmonicida. FEMS Microbiol. Lett. 9:39-42.

34. Trust, T. J., and R. A. H. Sparrow, 1974. The bacteria flora in the alimentary tract of freshwater salmonid fishes. Can. J. Microbiol. 20:1219-1228. 